\title{
Numerical Simulations for Undrained Shear Behavior of Soft Rocks
}

\author{
Saiichi SAKAJO*, Masao HAYASHI**, Takeshi KAMEI ${ }^{* * *}$ and Jin-Chun CHAI****
}

\begin{abstract}
The undrained shear behavior of soft rocks consisting of clayey sand and silty clay is simulated by applying an elasto-viscoplastic soil model to the Finite Element Method(FEM). The model parameters are empirically determined based on plasticity index(PI). Comparison with test data shows that the analysis can explain the laboratorymeasured behavior of soft rocks for a wide range of consolidation pressure and for both normally and overconsolidated states. The results indicate that (1) for clayey soft rock, the behavior can be represented by an elasto-viscoplastic model, and (2) the empirical method of determining the model parameters can be used where there is insufficient test information to directly define the model parameters. The computed and the observed undrained shear behavior are discussed by a detailed analysis of stress-strain, excess pore pressure-strain and effective stress paths. The effects of viscid model parameters on the mechanical behavior of the soil model used are also discussed.
\end{abstract}

Key words : consistency limits, numerical analysis, soft rock, undrained shear

\section{Introduction}

A compressed air energy storage system (CAES) has been proposed for the use in future urban development ${ }^{1)}$, to achieve more effective energy utilisation and sewage water purification. An important part of the CAES is an underground tank sited at a depth of several hundreds meters. In Tokyo area, thick soft rock deposit widely distributed, and they will be encountered in deep excavation. As part of basic research for the CAES, the mechanical behavior of soft rock in Tokyo area is under investigation.

A series of laboratory tests was conducted on samples obtained from depths of up to $600 \mathrm{~m}^{2}$. Although laboratory test results provide the basic information about the mechanical behavior of the samples, the number of samples and stress paths which can be tested are limited. Furthermore, for the design of the actual CAES tank, it is highly desirable to simulate the performance of the whole structure. Therefore, development of a model to describe the mechanical behavior of soft

\footnotetext{
* Kiso-Jiban Consultants Co., Ltd.

$* *$ Department of Civil Engineering, Tokai University ***Department of Geoscience, Shimane University(会員) ****Institute of Lowland Technology, Saga University
}

rock is necessary.

As a first approach, laboratory triaxial test results for clayey soft rock are simulated numerically by Finite Element Method(FEM). This paper first briefly describes the laboratory test conditions $^{2)}$, and the soil model used and the parameter determination are then presented. The simulated results are compared with test data and the implications of the results are discussed. The effect of viscid model parameters on the performance of the model used is also ascertained.

The purpose of this paper is to investigate whether it is possible to predict the undrained shear behavior of soft rock using the elastoviscoplastic model and soil parameters estimated by plasticity index(PI). The computed and the observed undrained shear behavior are discussed by a detailed analysis of stress-strain, excess pore pressure- strain and effective stress paths.

\section{Samples and test conditions}

In this study, test results of the samples from the Sodegaura site are considered. At Sodegaura ${ }^{2)}$, the top $10.6 \mathrm{~m}$ is reclaimed or alluvial soil. The Shimosa-Sogun soft rock deposit occurs from 10.6 to $307.4 \mathrm{~m}$ and is underlain by the Kazusa-Sogun soft rock deposit. From grain size distributions, 
the soft rock deposits at Sodegaura can be classified as clayey sands or silty clays.

A series of triaxial compression tests was conducted for samples from various depths, with a sampling interval of $50 \mathrm{~m}$ down to $600 \mathrm{~m}$ depth. In the laboratory, samples were isotropically consolidated before shear, and the consolidation pressures selected were equal to, lower and higher than in-situ overburden pressure. After the completion of isotropic consolidation, undrained compression shearing was performed, usig a sample size of $35 \mathrm{~mm}$ in diameter and $80 \mathrm{~mm}$ in height, and axial strain rate of $0.1 \% / \mathrm{min}$. The laboratory test program has been described in detail by KAWASAKI et $a l_{.}{ }^{2)}$. The depths selected for numerical simulation are $100 \mathrm{~m}, 400 \mathrm{~m}$, and $600 \mathrm{~m}$.

\section{Soil model used and parameter determi- nation}

To simulate the behavior of soft rock, the soil model should be able to represent: (1) elastoplastic behavior, (2) dilatancy, (3) softening, and (4) certain degrees of creep effect. SEKIGUCHI and OHTA $^{3)}$ proposed a visco-plastic model, which can consider the above-mentioned factors and is used in this study. This model has been widely used for simulating the behavior of soft to stiff clay in Japan. In isotropic and non-viscid case, the model is identical to the Cam clay model ${ }^{4)}$. Details of SEKIGUCHI and OHTA model will be explained further later.

In practice, it is difficult to obtain high quality undisturbed soil samples and conduct sufficient laboratory tests to define the model parameters, because it is costly and time consuming, especially for a very deep deposit. For this reason, several attempts have been made to empirically relate the mechanical properties of soil to index properties $^{5)}$. For cohesive soils the most commonly used index is plasticity index(PI).

Based on a series of laboratory test results, $\mathrm{KAMEI}^{6)}$ and NAKASE et al. ${ }^{7)}$ proposed an empirical method to estimate all model parameters for SEKIGUCHI and OHTA's elasto-viscoplastic model from plasticity index of soil. This method is very useful because only a small amount of disturbed soil sample is required to determine plasticity index. Although the method may not predict exact values for all cases, it has been shown that generally good estimates of model parameters are provided ${ }^{8}$. The method is also used in this study to test its applicability to soft rock.

The empirical equations for determining the soil parameters are summarized in Table 1. For
Table 1 Empirical relations between PI and soil parameters ${ }^{6 \sim 8}$

\begin{tabular}{|c|c|c|}
\hline No. & Parameter & Relationship \\
\hline 1 & 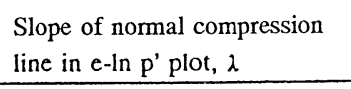 & $\lambda=0.02+0.0045 \mathrm{PI}$ \\
\hline 2 & $\begin{array}{l}\text { Slope of unloading-reloading } \\
\text { line in e-In p' plot, } x\end{array}$ & $x=0.00084(P I-4.6)$ \\
\hline 3 & $\begin{array}{l}\text { Void ratio for normally } \\
\text { consolidated state at } \\
\mathrm{p}^{\prime}=10 \mathrm{tf} / \mathrm{m}^{2}, \mathrm{e}_{\circ}\end{array}$ & $\mathrm{e}_{0}=0.517+0.019 \mathrm{PI}$ \\
\hline 4 & $\begin{array}{l}\text { Slope of compression failure } \\
\text { line in } q-p^{\prime} \text { plot, } M_{C}\end{array}$ & $\mathrm{M}_{\mathrm{C}}=1.65$ \\
\hline 5 & $\begin{array}{l}\text { Slope of Extension failure } \\
\text { line in } q-p^{\prime} \text { plot, } M_{E}\end{array}$ & $\mathrm{M}_{\mathrm{E}}=1.385-0.00505 \mathrm{PI}$ \\
\hline 6 & $\begin{array}{l}\text { Coefficient of secondary } \\
\text { compression, } \mathrm{C}_{\alpha} \\
\text { (or secondary compression } \\
\text { index, } \alpha)\end{array}$ & $\begin{array}{l}C_{\alpha}=0.00168+0.00033 \mathrm{PI} \\
\alpha=0.434 C_{\alpha} /\left(1+\mathrm{e}_{0}\right)\end{array}$ \\
\hline 7 & $\begin{array}{l}\text { Coefficient of normally } \\
\text { consolidated lateral earth } \\
\text { pressure, } \mathrm{K}_{\mathrm{ONC}}\end{array}$ & $\mathrm{K}_{\mathrm{ONC}}=0.45$ \\
\hline 8 & $\begin{array}{l}\text { Coefficient of } \\
\text { overconsolidated lateral earth } \\
\text { pressure, } K_{0 O C}\end{array}$ & $\mathrm{~K}_{\mathrm{OOC}}=\mathrm{K}_{\mathrm{ONC}}(\mathrm{OCR})^{0.45}$ \\
\hline 9 & Poisson's ratio, v' & $v^{\prime}=K_{O N C} /\left(1+K_{O N C}\right)$ \\
\hline 10 & 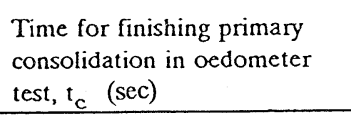 & $\mathrm{t}_{\mathrm{c}}=17.77 \mathrm{PI}$ \\
\hline 11 & $\begin{array}{l}\text { Initial volumetric strain rate, } \\
\dot{\mathrm{v}}_{0}(1 / \mathrm{sec})\left(\mathrm{X} 10^{-4}\right)\end{array}$ & $\dot{\mathrm{V}}_{0}=0.434 \mathrm{C}_{\mathrm{\alpha}} /\left(1+\mathrm{c}_{0}\right) / \mathrm{t}_{\mathrm{c}}$ \\
\hline
\end{tabular}

Table 2 Soil parameters estimated by PI

\begin{tabular}{c|c|c|c|c|c|c|c|c}
\hline Depth (m) & PI & $\lambda$ & $\kappa$ & M (=Mc) & $e_{0}$ & $\mathrm{C}_{a}$ & $\alpha$ & $\dot{\mathrm{V}}_{\circ}\left(\mathrm{X} 10^{-10}\right)$ \\
\hline 100 & 22.9 & 0.123 & 0.015 & 1.65 & 0.952 & 0.00924 & 0.00205 & 5.04 \\
\hline 400 & 26.3 & 0.138 & 0.018 & 1.65 & 1.017 & 0.01034 & 0.00223 & 4.77 \\
\hline 600 & 26.2 & 0.137 & 0.018 & 1.65 & 1.015 & 0.01033 & 0.00222 & 4.48 \\
\hline
\end{tabular}

the samples at $100 \mathrm{~m}, 400 \mathrm{~m}$, and $600 \mathrm{~m}$ depth, the plasticity index(PI) is 22.9, 26.3, and 26.2 respectively. The calculated model parameters are listed in Table 2.

A set of model parameters has been reported for the Sodegaura site by KANNO ${ }^{9}$, based on test data. The parameters calculated from PI are comparable with those reported by KANNO ${ }^{9}$. However, differences are apparent in the $\mathrm{M}$ and $\mathrm{C}_{\alpha}$ values. The empirical method gives an $\mathrm{M}$ value of 1.65 , compared to 1.5 from the test data. This difference is small, however, and of no great significance, shown that the predicted result gives realistic value when compared with observed values. For secondary consolidation coefficient, $\mathrm{C}_{\alpha}$, the values determined from PI is lower than the reported test values of 0.0180 (Depth:100m), 0.0186 
(Depth:400m), and 0.0185(Depth:600m) respectively, as shown in Table 2. This parameter is related to viscid behavior of the model and will be discussed further below.

\section{Numerical simulation}

For each depth selected, three consolidation pressures are used for simulation. These correspond to in-situ overburden pressure, half the insitu overburden pressure, and the maximum value (preconsolidation pressures) tested at each depth. Preconsolidation pressures are determined based on laboratory oedometer test results, as well as comparing simulated results with test data.

The laboratory oedometer results show that the deposit at Sodegaura is in a overconsolidated state. The overconsolidation ratio (OCR) at $100 \mathrm{~m}$ depth is about 6.0 , and below $200 \mathrm{~m}$ about 1.5 to 2.0 . However, comparing the numerical results with test values shows that if in-situ OCR value of 3.0 for $100 \mathrm{~m}$ samples and 1.0 for $400 \mathrm{~m}$ and $600 \mathrm{~m}$ samples are used, the numerical results yield a better fit to the test data. The possible reasons for reducing the OCR values are: (1) disturbance during sampling, and (2) the samples are consolidated isotropically, and not recompressed to in-situ stress. The stress state for the simulated samples are tabulated in Table 3.

\section{Comparisons of simulated and observed results}

The simulated results are compared with test data and discussed for: (1) deviatric stress-axial

Table 3 Stress condition of the samples simulated

\begin{tabular}{|c|c|c|c|c|c|c|}
\hline \multirow[t]{2}{*}{ No. } & \multirow[t]{2}{*}{$\begin{array}{l}\text { Depth } \\
\text { (m) }\end{array}$} & \multicolumn{2}{|c|}{$\begin{array}{l}\text { Initial Consolidation } \\
\text { Pressure }\left(t \mathrm{t} / \mathrm{m}^{2}\right)\end{array}$} & \multicolumn{2}{|c|}{$\begin{array}{l}\text { Preconsolidation } \\
\text { Pressure }\left(\mathfrak{t f} / \mathrm{m}^{2}\right)\end{array}$} & \multirow[t]{2}{*}{ Remarks } \\
\hline & & $\sigma_{1}^{\prime}$ & $\sigma_{3}{ }^{\prime}$ & $\sigma_{\mathrm{v}_{\mathrm{m}}}{ }^{\prime}$ & Ko & \\
\hline 1 & \multirow{3}{*}{100} & 45 & 45 & 270 & 0.45 & $\mathrm{OC}^{*}$ \\
\hline 2 & & $90^{*}$ & 90 & 270 & 0.45 & OC \\
\hline 3 & & 360 & 360 & 360 & 1.00 & $\mathrm{NC} *$ \\
\hline 4 & \multirow{3}{*}{400} & 180 & 180 & 360 & 0.45 & OC \\
\hline 5 & & $360^{*}$ & 360 & 360 & 1.00 & $\mathrm{NC}$ \\
\hline 6 & & 940 & 940 & 940 & 1.00 & $\mathrm{NC}$ \\
\hline 7 & \multirow{3}{*}{600} & 270 & 270 & 540 & 0.45 & OC \\
\hline 8 & & $540^{*}$ & 540 & 540 & 1.00 & $\mathrm{NC}$ \\
\hline 9 & & 900 & 900 & 900 & 1.00 & $\mathrm{NC}$ \\
\hline
\end{tabular}

* : The values are corresponding to in-situ overburden pressure

\# : OC (overconsolidated state), NC (normally consolidated state) strain $\left(q-\varepsilon_{\mathrm{a}}\right)$ curves, (2) excess pore pressureaxial strain $\left(\Delta u-\varepsilon_{\mathrm{a}}\right)$ curves, and (3) effective stress paths. The test data are all reproduced from KAWASAKI et al. ${ }^{2)}$.

(1) $100 \mathrm{~m}$ depth samples.

Figures 1 to 3 show the $q-\varepsilon$ and $\Delta \mathrm{u}-\varepsilon_{\mathrm{a}}$ curves, and Fig.4 gives the comparison of effective stress paths for $100 \mathrm{~m}$ depth samples. It can be seen that the analysis yields acceptable results, although excess pore pressure is slightly overestimated. For OC samples (Figs.1 and 2), the simulated $q-$ $\varepsilon_{\text {a }}$ curves shows a linear elastic-perfect plastic pattern. On $\Delta u-\varepsilon_{\text {a }}$ curves, peak value of excess pore pressure occurs, corresponding to the yield point on q- $\varepsilon_{\text {a }}$ curves.

The effective stress path of OC samples first follows a $p^{\prime}$ constant path until it reaches the HVORSLEV failure line ${ }^{10)}$. Then, the HVORSLEV strength line is followed to the critical state line. However, the measured effective stress path is

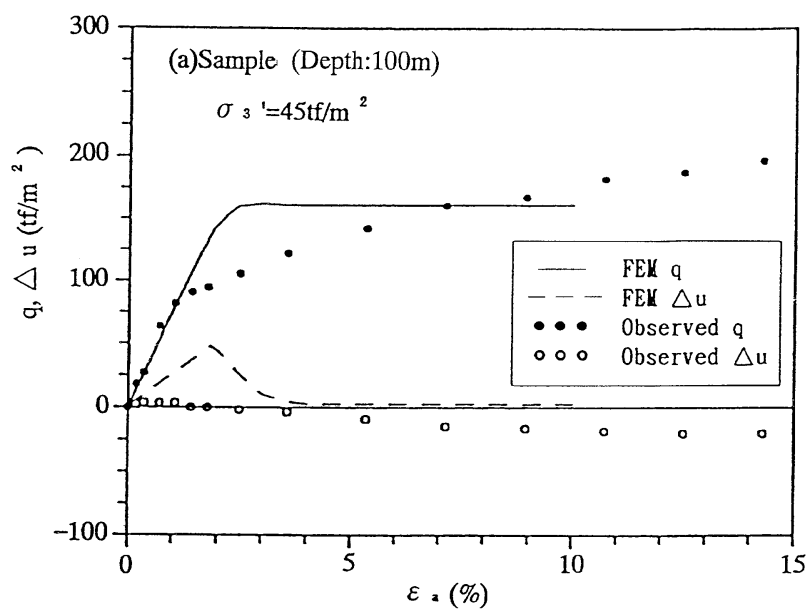

Fig. 1 Comparison of computed and observed stress-strain and excess pore pressure-strain behavior during $\operatorname{shear}\left(\right.$ Depth:100m, $\left.\sigma_{3}{ }^{\prime}=45 \mathrm{tf} / \mathrm{m}^{2}\right)$

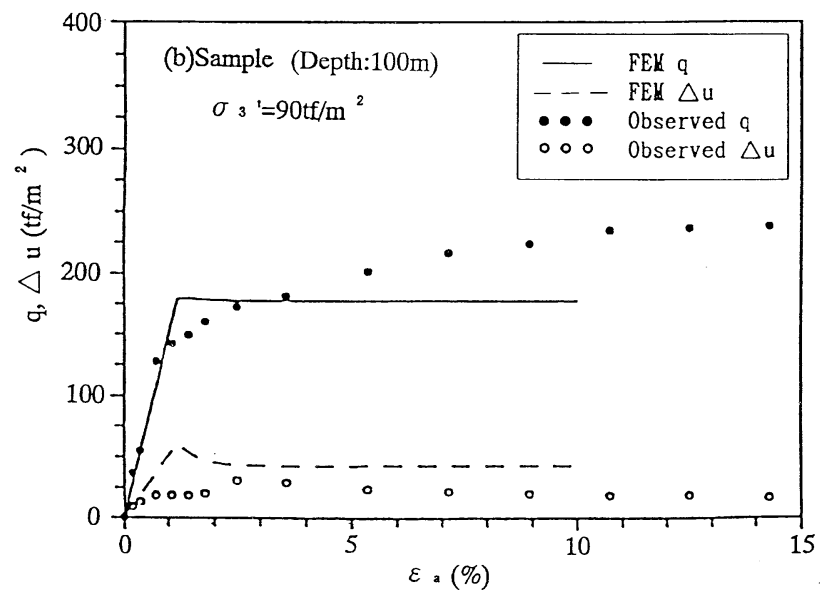

Fig. 2 Comparison of computed and observed stress-strain and excess pore pressure-strain behavior during shear (Depth:100m, $\sigma_{3}{ }^{\prime}=90 \mathrm{tf} / \mathrm{m}^{2}$ ) 


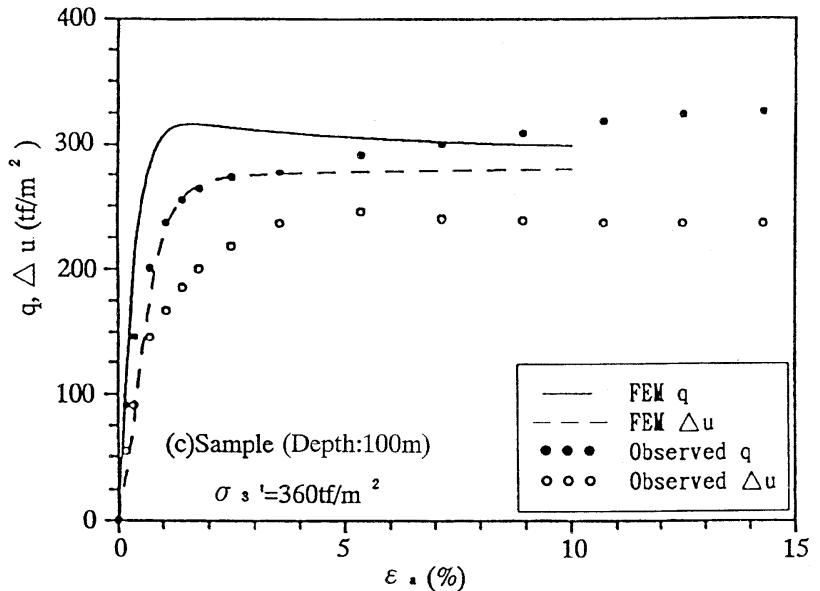

Fig. 3 Comparison of computed and observed stress-strain and excess pore pressure-strain behavior during shear (Depth:100m, $\sigma_{3}{ }^{\prime}=360 \mathrm{tf} / \mathrm{m}^{2}$ )

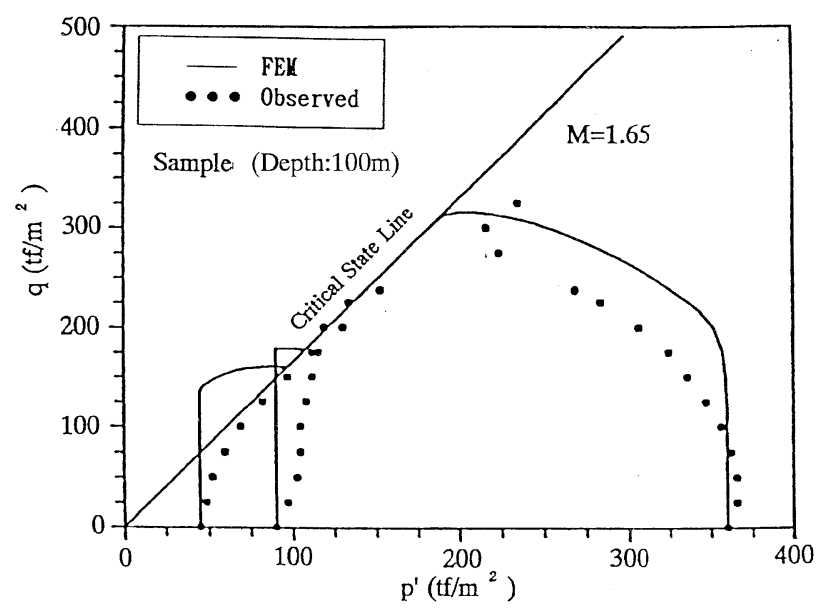

Fig.4 Comparison of computed and observed effective stress paths (Depth:100m)

not vertical (Fig.4), and the difference between the simulated and the measured effective stress path is obvious (Fig.4). This can be regarded as a limitation of the Cam clay type ${ }^{4)}$ soil model for heavily overconsolidated samples.

For normally consolidated sample, from both Fig.3 and Fig.4, it can be seen that the simulated initial strength mobilization rate is higher than the test results. Figure 4 also indicates that the test data of OC samples yield a $M$ value of 1.65 , whereas, NC samples have an $M$ value of about 1.36 as reported by $\mathrm{KANNO}^{9)}$.

(2) $400 \mathrm{~m}$ depth samples.

Figures 5 to 7 show the $q-\varepsilon_{\text {a }}$ and $\Delta u-\varepsilon_{\text {a }}$ curves for $400 \mathrm{~m}$ depth samples. The simulation yields a lower strength for 180 , and $360 \mathrm{tf} / \mathrm{m}^{2}$ confining pressure cases (Figs. 5 and 6), but a higher strength for the $940 \mathrm{tf} / \mathrm{m}^{2}$ confining pressure case (Fig.7). However, the simulated excess pore pressure fit test data quite well. Generally, it is

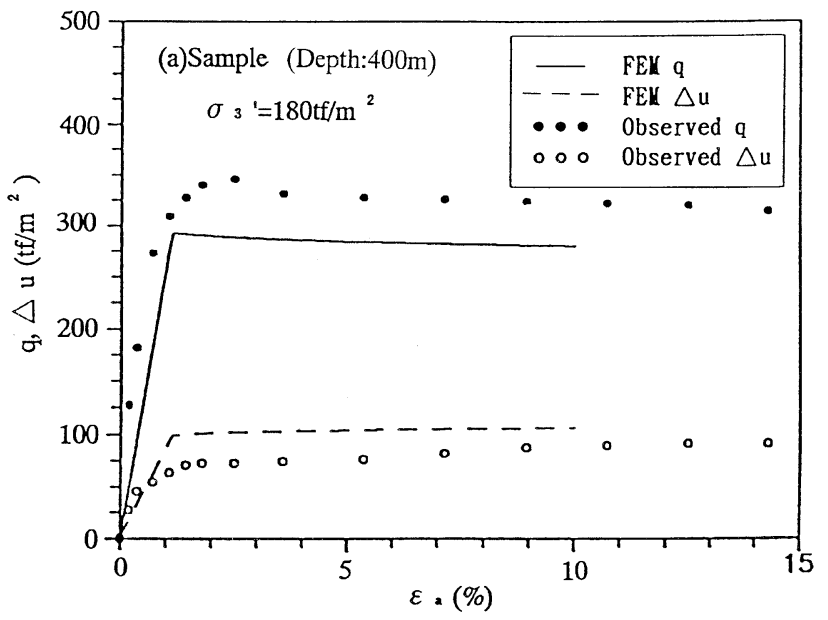

Fig. 5 Comparison of computed and observed stress-strain and excess pore pressure-strain behavior during shear (Depth:400m, $\sigma_{3}{ }^{\prime}=180 \mathrm{tf} / \mathrm{m}^{2}$ )

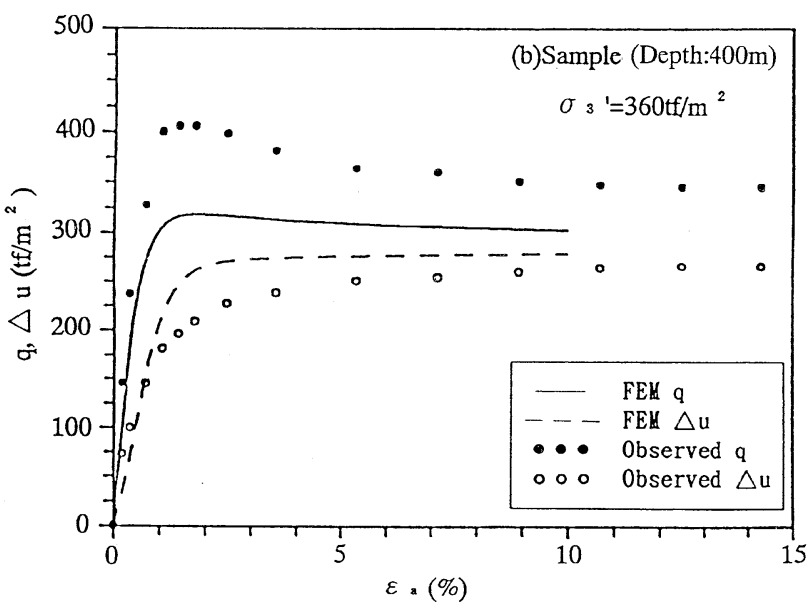

Fig. 6 Comparison of computed and observed stress-strain and excess pore pressure-strain behavior during $\operatorname{shear}\left(\right.$ Depth: $400 \mathrm{~m}, \sigma_{3}{ }^{\prime}=360 \mathrm{tf} / \mathrm{m}^{2}$ )

considered that the calculated results are reasonable.

The effective stress paths for $400 \mathrm{~m}$ depth samples are given in Fig.8, and show that test data gives an $M$ value close to 1.65 . For OC sample, the predicted stress path is vertical, and in this case it is close to that measured. For NC samples, the shape of the predicted effective stress path is similar to that measured, but details of the simulated results differ from the experimental results for the effective stree paths. From Fig.8, it can also be seen that in the case where confining pressure equals the in-situ overburden pressure (360 $\mathrm{tf} / \mathrm{m}^{2}$ ), the sample might be in a slightly overconsolidated state. However, the analysis assumes to be in a normally consolidated state for the samples. Overestimation of the strength for the 940tf $/ \mathrm{m}^{2}$ confining pressure case may due to viscid 


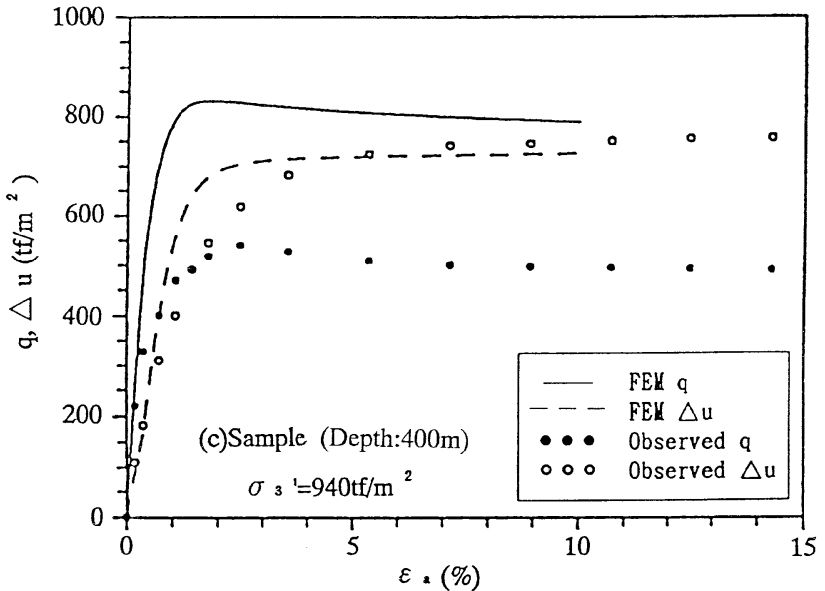

Fig. 7 Comparison of computed and observed stress-strain and excess pore pressure-strain behavior during shear(Depth:400m, $\sigma_{3}{ }^{\prime}=940 \mathrm{tf} / \mathrm{m}^{2}$ )

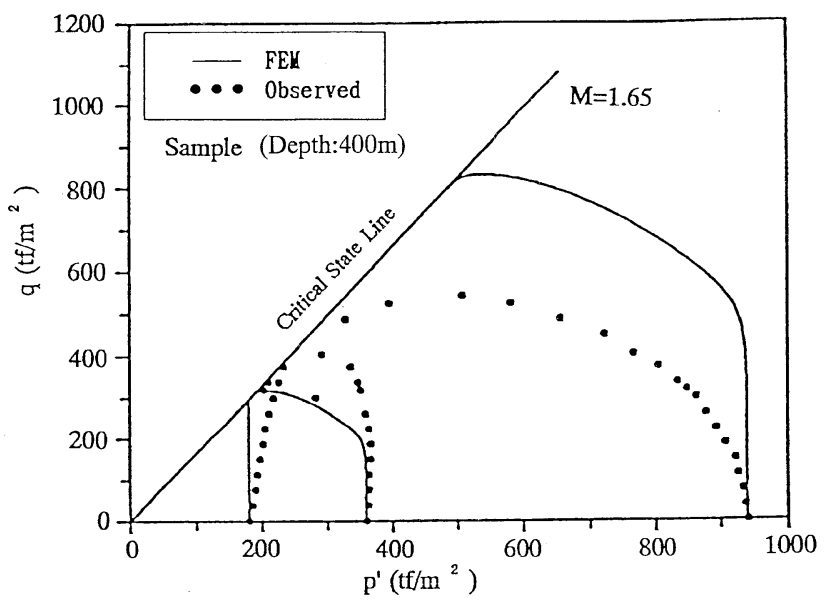

Fig. 8 Comparison of computed and observed effective stress paths (Depth:400m)

effect in the model. This factor will be discussed in the next section.

(3) $600 \mathrm{~m}$ depth samples.

The $q-\varepsilon_{\mathrm{a}}$ and $\Delta u-\varepsilon_{\mathrm{a}}$ curves are given in Figs.9 to $\mathbf{1 1}$ for confining pressures of 270,540 , and 900 $\mathrm{tf} / \mathrm{m}^{2}$, respectively. The results are similar to the $400 \mathrm{~m}$ depth samples. The excess pore pressure prediction is good, on the other hand, details of the simulated results differ from the experimental results for strss-strain behavior. The numerical results underestimate the strength for OC sample (Fig.9). For the sample with $900 \mathrm{tf} / \mathrm{m}^{2}$ confining pressure, the numerical results overestimate the peak strength, but underestimate softening (Fig.11). The model simulation, however, is capable of predicting qualitatively the salient features of stress-strain behavior.

The effective stress paths are shown in Fig.12. It can be seen that for this analysis, the calculated stress path shows a better fit with that measured,

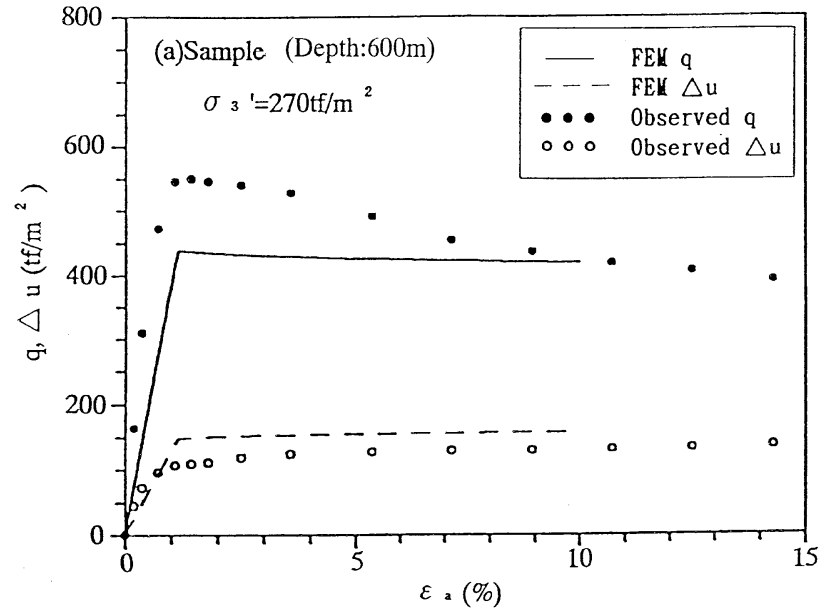

Fig. 9 Comparison of computed and observed stress-strain and excess pore pressure-strain behavior during shear (Depth:600m, $\sigma_{3}{ }^{\prime}=270 \mathrm{tf} / \mathrm{m}^{2}$ )

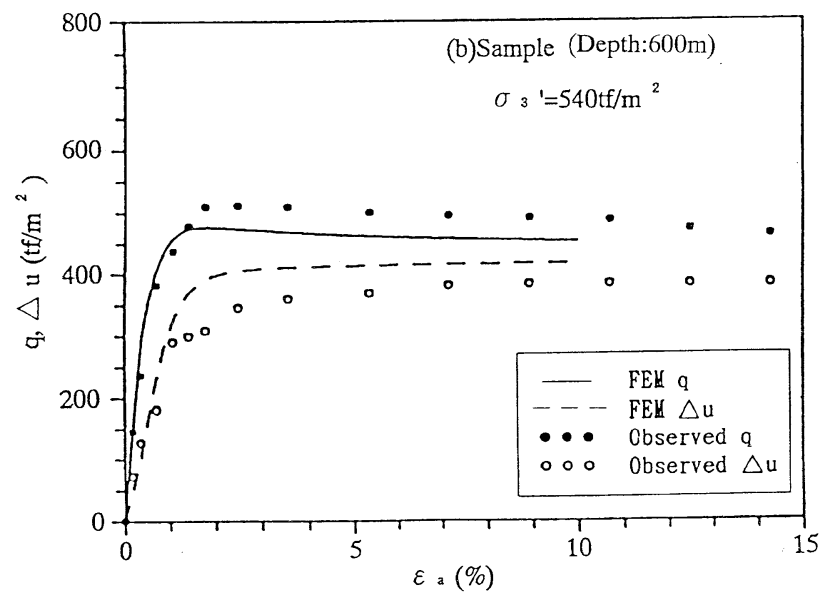

Fig.10 Comparison of computed and observed stress-strain and excess pore pressure-strain behavior during shear (Depth:600m, $\sigma_{3}{ }^{\prime}=540 \mathrm{tf} / \mathrm{m}^{2}$ )

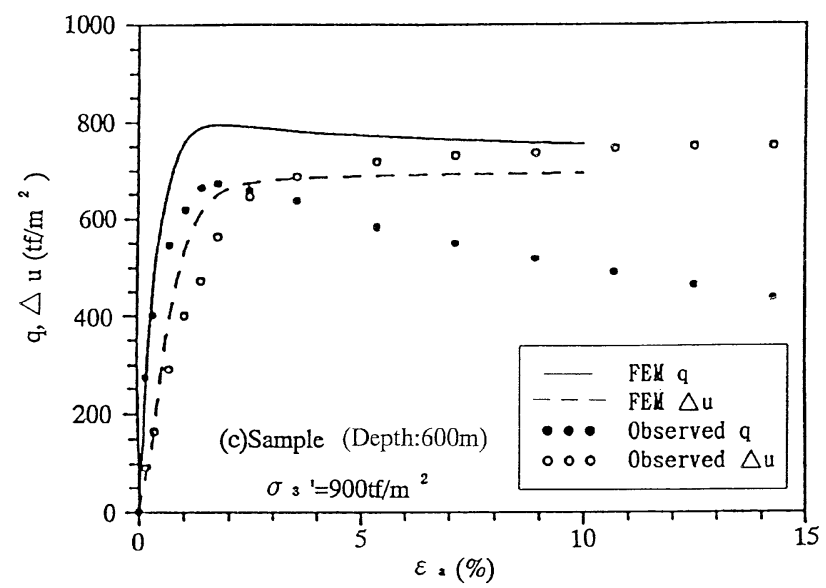

Fig.11 Comparison of computed and observed stress-strain and excess pore pressure-strain behavior during shear (Depth:600m, $\sigma_{3}{ }^{\prime}=900 \mathrm{tf} / \mathrm{m}^{2}$ ) 


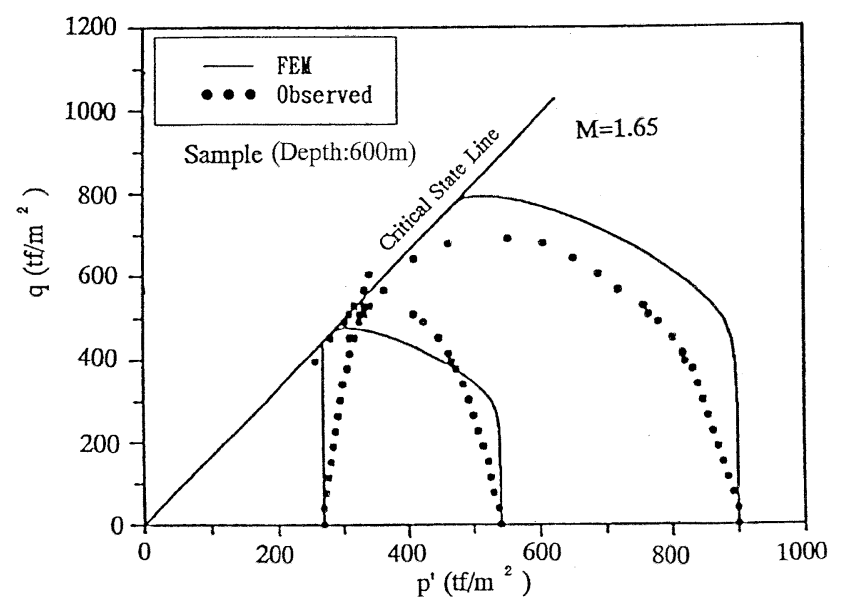

Fig.12 Comparison of computed and observed effective stress paths (Depth:600m)

and an $M$ value of 1.65 is supported by the test data.

From the above comparison, it can be seen that the behavior of soft rock under triaxial undrained loading condition can be reasonably explained by an elasto-viscoplastic model for a wide range of confining pressure and for both normally and overconsolidated states. From an overall point of view, the predicted excess pore pressures are very close to test data. For undrained strength, although details of the simulated results differ from the experimental results, the model simulation is capable of predicting qualitatively. This may be due to limitations of the model and uncertainty in in-situ preconsolidation pressure.

This study illustrates that the empirical method of estimating the model parameters can be applied to soft rock. Therefore, it is suggested that for primary study or where no detailed information to determine the model parameters exists, the empirical equations between PI and model parameters can be used.

\section{Effect of viscid model parameters on undrained shear strength}

Using an elasto-viscoplastic model is more difficult than an elasto-plastic model because of interaction between the model parameters. The effect of viscid parameters on the performance of SEKIGUCHI and OHTA's model is discussed here to better explain the simulated results presented above. In the case of normally consolidated state, the model has been established using on the volumetric creep equation ${ }^{3)}$ :

$$
v=\lambda /\left(1+e_{0}\right) \cdot \ln \left(p^{\prime} / p_{0}{ }^{\prime}\right)+D \eta^{*}-\alpha \ln \left(\dot{v} / \dot{v}_{0}\right)
$$

Where $v$ is volumetric strain, $e_{0}$ is initial void ratio, $\dot{v}$ is the volumetric strain $\operatorname{rate}(\dot{v}>0.0), p^{\prime}$ is mean effective stress, $p_{0}{ }^{\prime}$ is the initial mean effective stress, $D=(\lambda-\kappa) / M\left(1+e_{0}\right)$ is a dilatancy parameter, $\lambda$ is a compression index, $\kappa$ is a swelling index, and $M$ is a slope of Critical State Line in triaxial tests. In addition, $\eta^{*}=\sqrt{3\left(\eta_{i j}-\eta_{i j o}\right)}$ $\left(\eta_{i j}-\eta_{i j o}\right) / 2$ is the deviatric stress tensor, where $\eta_{\mathrm{ij}}=\sigma_{i j} / \mathrm{p}^{\prime}-\delta_{i j}, \eta_{i j 0}=\sigma_{i j} / p_{0}{ }^{\prime}-\delta_{i j}$ and $\alpha=0.434$ $\mathrm{C}_{\alpha} /\left(1+e_{0}\right)$ is the secondary compression index. SEKIGUCHI and OHTA model have been described in detail elsewhere ${ }^{3,6), 8), 11)}$. The volumetric strain consists of three terms: (1) isotropic compression term, $\lambda /\left(1+e_{0}\right) \cdot \ln \left(p^{\prime} / p_{0}{ }^{\prime}\right)$, (2) dilatancy term, D $\eta^{*}$, and (3) creep term, $-\alpha \ln \left(\dot{v} / \dot{v}_{0}\right)$. The viscid parameters, $\alpha$ and $\dot{v}_{0}$ will influence the 3rd term of the volumetric strain. If $\dot{v}$ is larger than $\dot{v}_{0}$, the 3 rd term is negative, which implies viscosity effect, and when $\dot{v}$ is less than $\dot{v}_{0}$, the 3 rd term is positive, implying creep effect. $\alpha$ has an effect on the magnitude of the 3rd term.

In Eq.(1), $\eta^{*}$ is not negative, therefore, the 2nd term is always positive. In the case where the $3 \mathrm{rd}$ term is negative $\left(\dot{v}>\dot{v}_{0}\right)$, and if the sum of the 2 nd and 3rd terms is zero, $p^{\prime}$ remains constant and the stress path is vertical. Therefore, under the condition of $\dot{v}>\dot{v}_{0}$, the smaller the $\dot{v}_{0}$ and the larger the $\alpha$, the higher the undrained shear strength will be.

In the case where the sum of the 2 nd and 3rd terms is positive, in order to maintain the undrained condition, $p^{\prime}$ needs to be reduced to less than $p_{0}{ }^{\prime}$. When the stress state is close to the critical state and the stress path is parallel to the critical state line, the 2 nd term remains constant. Further, change in the 3rd term(magnitude or sign) requires change in $p^{\prime}$, and hardening (negative 3rd term and increase of $p^{\prime}$ ) or softening (positive 3rd term and reduction of $p^{\prime}$ ) phenomena can be predicted.

Figures 13 and 14 illustrate the effect of $\alpha$ and $\dot{v}_{0}$ on the computed effective stress path. For Figs.13 and 14, the parameters for the $400 \mathrm{~m}$ depth case are used as the basic conditions (Table 2). It is assumed that the sample is isotropically, normally consolidated with a pressure of $360 \mathrm{tf} / \mathrm{m}^{2}$ before shear. The results of elasto-plastic analysis is also shown in the figures. Figure 13 shows that the calculated undrained shear strength increases with reduction in $\dot{v}_{0}$. It can also be seen that the effective stress path of the elasto-viscoplastic analysis can lie below the elasto-plastic analysis at larger $\dot{v}_{0}$ values. Larger $\dot{v}_{0}$ value implies that the 3rd term in Eq.(1) may be always positive, and more reduction in p' is required to maintain the undrained condition. Figure 14 indicates that for 


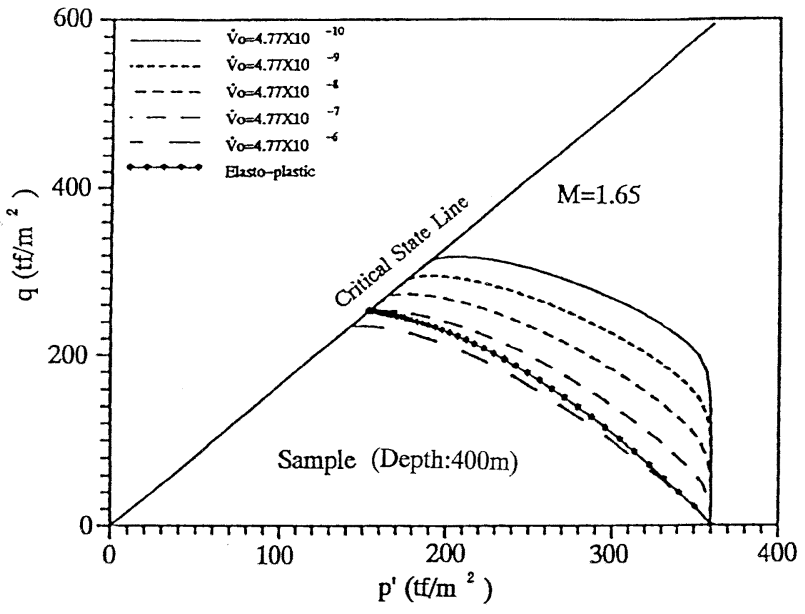

Fig. 13 Effect of $\dot{v}_{0}$ on the computed effective stress path

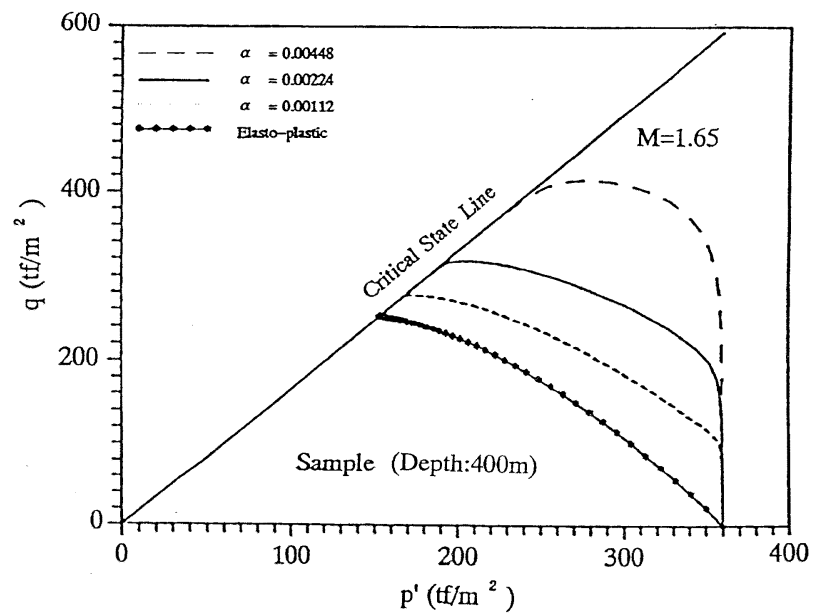

Fig. 14 Effect of $\alpha$ on the computed effective stress path

the parameters used, the larger the $\alpha$ value, the higher the undrained shear strength(3rd term is negative).

Based on this fundamental understanding, it can be seen that viscid model parameters have a strong effect on the performance of the model. It is also apparent that the viscid parameters adopted in this study yield a higher strength than the elasto-plastic analysis. In this study, a better prediction of undrained shear strength for normally consolidated samples might be achieved by reducing $\alpha$ or increasing $\dot{v}_{0}$ values. However, it seems that more work is needed on how to estimate the initial volumetric strain rate if a viscoplastic model is used.

\section{Conclusions}

A visco-plastic model is used to simulate the undrained behavior of soft rocks sampled from the Sodegaura site near Tokyo. The model parameters are empirically determined from plasticity index(PI). By comparison with test data, it is found that predictions of undrained shear strength differ from the experimental results slightly, but excess pore pressures fit the test data quite well. Generally, the model can explain the behavior of soft rocks for a wide range of consolidation pressure and for both normal and overconsolidated states.

The empirical method of determining the model parameters can be applied to soft rocks. Where insufficient information expects to directly define the model parameters, the empirical relationships between PI and the model parameters can be used.

For the elasto-viscoplastic model used, the viscid model parameters, $\alpha$ and $\dot{v}_{0}$, have a significate effect on the performance of the model. Numerical results indicate that under the conditions where volumetric strain rate, $\dot{v}$ (related to the speed of shearing etc.), is larger than the initial volumetric strain rate, $\dot{v}_{0}\left(\dot{v}>\dot{v}_{0}\right)$, the smaller the $\dot{v}_{0}$ and the larger the $\alpha$ value are, the higher the predicted undrained strength will be.

\section{References}

1) HAYASHI, M.(1993): Urban water purification and compressed air electricity storage - future of CAES-GT system, Tsuchi-To-Kiso, JSSMFE, Vol.41, No. 11, pp. 7-9.*

2 ) KAWASAKI, S., NISHI, K., FUJIWARA, Y. and OKAMOTO, T.(1993): Mechanical properties of deep soft rock ground for compressed air energy storage-property evaluation based on laboratory test using undisturbed samples, Abiko Research Laboratory, Rep. No.U93021, 89p.*

3 ) SEKIGUCHI, H. and OHTA, H.(1977): Induced anisotropy and time dependency in clay, Proceedings of 9th International Conference on Soil Mechanics and Foundation Engineering, Specialty Session 9, Tokyo, Japan, pp.229-238.

4 ) ROSCOE, K.H. and BURLAND, J.B.(1968): On the generalized stress-strain behavior of wet clays, Proceedings of Engineering Plasticity, Cambridge, Cambridge Univ. Press, pp.535-609.

5 ) WOOD, D.M.(1990): Soil behavior and critical state soil mechanics, Cambridge University Press, 462p.

6 ) KAMEI, T.(1985): A study on the mechanical behaviour of normally consolidated cohesive soils, thesis presented to the Tokyo Institute of Technology, Japan, in partial fulfillment of the requirements for the degree of Doctor of Engineering, 339p.

7) NAKASE, A., KAMEI, T. and KUSAKABE, O.(1988): Constitutive parameters estimated by plasticity index, Journal of Geotechnical Engineering, American Society of Civil Engineering, Vol.114, No.7, pp.844-858.

8 ) KAMEI, T. and SAKAJO, S.(1993): Settlement analyses of embankment foundation using elasto-viscoplastic model, Tsuchi-to-Kiso, JSSMFE, Vol. 41, No. 2, pp. 23-28. *

9 ) KANNO, M.(1993): Research on construction of underground tank for water purification and compressed air electricity energy storage system, Master Thesis, Nippon University, 145p. *

$10)$ HVORSLEV, M.J.(1960): Physical components of the shear strength of saturated clay, Proceedings of Research 
Conference on Shear Strength of Cohesive Soils, American Society of Civil Engineering, pp.169-273.

11) KAMEI, T. and SAKAJO, S.(1995): Evaluation of undrained shear behaviour of Ko-consolidated cohesive soils using elasto-viscoplastic model, Computers and Geotechnics, Vol.17, No.3, pp.397-417.

\section{Appendix}

*: in Japanese with English abstract

（1998年 2 月 9 日受付, 1998年 4 月 8 日受理)

応用地質，第39巻，第 4 号，372-379頁，1998

\title{
軟岩の非排水せん断挙動に関する数值シミュレーション
}

\author{
阪上最一・林 正夫・亀井健史・紫 錦春
}

\section{要 旨}

粘土質抢よびシルト質軟岩の非排水せん断挙動を土の弾粘塑性モデルを用いて, 有限要素法によりシミュレートした。また， 数值解析に用いた土質定数は工学的観点から塑性指数から決定した. また, 得られた数値解析結果の信頼性を検討するため, 応 力一ひずみ関係, 過剩間隙水圧一ひずみ関係, さらには有効応力経路に関して, 実測結果と数値解析結果とを比較検討した。

結果として, 本解析法に基づいた数值解析法は, 異なる圧密圧力さらには正規圧密・過圧密状態によらず, 軟岩の非排水せん 断挙動をよく再現できる手法であることが示唆された.

キーワード : コンシステンシー限界, 数值解析, 軟岩, 非排水せん断 